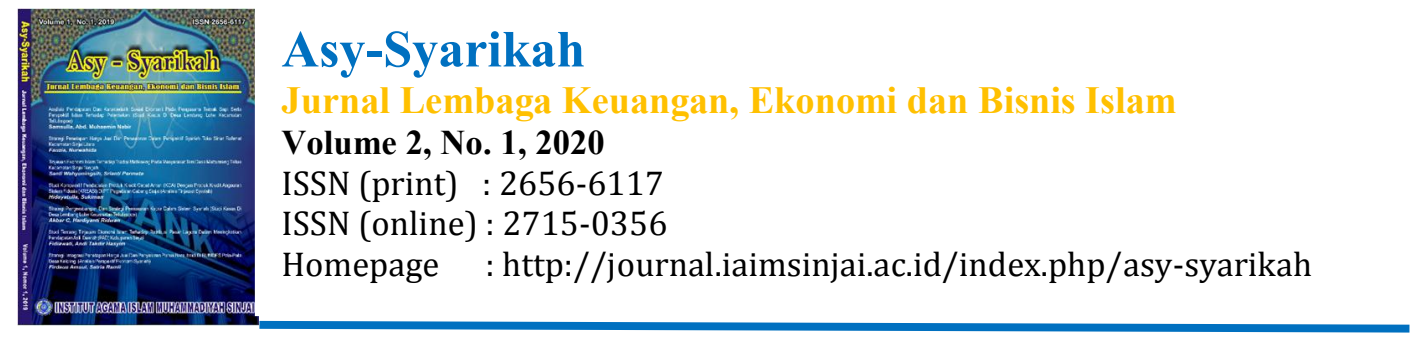

\title{
PENDEKATAN LOCATION QUESTION,SHIFT SHARE DAN TIPOLOGI KLASSEN TERHADAP POTENSI SEKTOR EKONOMI DI KABUPATEN BONE
}

\author{
Sahiruddin ${ }^{1}$ \\ STKIP Muhammadiyah Bone \\ Email/Tlp : ayiamali88cl@gmail.com/085298373374
}

\begin{abstract}
Abstrak
Penelitian ini bertujuan untuk mengetahui sektor ekonomi yang menjadi sektor basis dan non basis, perubahan atau pergeseran sektor perekonomian, serta mengetahui klasifikasi pertumbuhan sektor perekonomian Kabupaten Bone. Populasi dalam penelitian adalah data PDRB Kabupaten Bone dan Provinsi Sulawesi Selatan tahun 2011-2015, yang sekaligus sebagai sampel. Pengumpulan data dilakukan dengan teknik Dokumentasi dan wawancara. Analisis data yang digunakan adalah dengan menggunakan Analisis Location Qoutient (LQ), Shift Share dan Tipologi Klassen. Hasil analisis penelitian menunjukkan bahwa Location Quotient sektor Pertanian, Kehutanan, dan Perikanan, Pengadaan Listrik dan Gas, Administrasi Pemerintahan, Pertahanan dan Jaminan Sosial, merupakan sektor basis. Analisis Shift Share (SS) menunjukkan bahwa sektor yang merupakan sektor kompetitif adalah sektor Pertanian, Kehutanan, dan Perikanan, Pertambangan dan Penggalian, Pengadaan Listrik dan Gas, Perdagangan Besar dan Eceran; Reparasi Mobil dan Sepeda Motor, Transportasi dan Pergudangan, Penyediaan Akomodasi dan Makan Minum, Jasa Keuangan dan Asuransi, Jasa Perusahaan, Jasa Pendidikan dan Jasa Kesehatan dan Kegiatan Sosial. Sedangkan analisis Tipology Klassen (TK) menunjukkan sektor yang maju dan tumbuh pesat adalah Pertanian, Kehutanan, dan Perikanan. Hasil analisis per sektor berdasarkan ketiga alat analisis menunjukkan bahwa sektor yang merupakan sektor unggulan di Kabupaten Bone dengan kriteria sektor maju dan tumbuh pesat, sektor basis dan kompetitif adalah sektor pertanian, kehutanan dan Perikanan.
\end{abstract}

Kata Kunci : Sektor Ekonomi di Kabupaten Bone-Basis -Non Basis

\begin{abstract}
Abstrack
This study aims to determine the economic sectors that are the basis and non-base sectors, changes or shifts in the economic sector, and determine the classification of growth in the economic sector of Bone Regency. The population in this study is the GDP of Bone Regency and South Sulawesi Province in 2011-2015, which is also a sample. Data collection is done by documentation and interview techniques. Furthermore, the analysis of the data used is to use Location Analysis Analysis (LQ), Shift Share and Typology Klassen. The results of the research analysis show that the Location Quotient in the Agriculture, Forestry and Fisheries, Electricity and Gas Procurement, Government Administration, Defense and Social Security sectors is a base sector. Shift Share (SS) analysis shows that the sectors which are competitive sectors are Agriculture, Forestry, and Fisheries, Mining and Quarrying, Electricity and Gas Procurement, Wholesale and Retail Trade; Car and Motorcycle Repair, Transportation and Warehousing, Provision of Accommodation and Food and Beverage, Financial Services and Insurance, Corporate Services, Educational Services and Health Services and Social Activities. While the Klassen Tipology (TK) analysis shows that the sectors that are progressing and growing
\end{abstract}




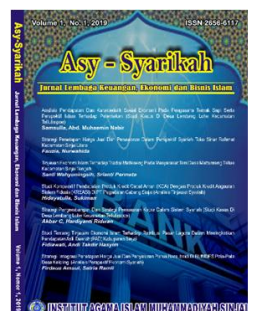

Asy-Syarikah

Jurnal Lembaga Keuangan, Ekonomi dan Bismis Islam

Volume 2, No. 1, 2020

ISSN (print) : 2656-6117

ISSN (online) : 2715-0356

Homepage : http://journal.iaimsinjai.ac.id/index.php/asy-syarikah

rapidly are Agriculture, Forestry, and Fisheries. The results of the analysis by sector based on the three analytical tools show that the sector which is the leading sector in Bone Regency with the criteria of developed and rapidly growing sectors, the base and competitive sectors are the agriculture, forestry and fisheries sectors.

Keywords: Economic Sector in Bone District - Base - Non Base

\section{Pendahuluan}

Pertumbuhan ekonomi adalah perkembangan kegiatan dalam perekonomian yang menyebabkan barang dan jasa yang diproduksikan dalam masyarakat bertambah dan kemakmuran masyarakat meningkat. Masalah pertumbuhan ekonomi dapat dipandang sebagai masalah makro ekonomi dalam jangka panjang. Perkembangan kemampuan memproduksi barang dan jasa sebagai akibat pertambahan faktor-faktor produksi pada umumnya tidak selalu diikuti oleh pertambahan produksi barang dan jasa yang sama besarnya. Pertambahan potensi memproduksi seringkali lebih besar dari pertambahan produksi yang sebenarnya. Dengan demikian perkembangan ekonomi adalah lebih lambat dari potensinya. (Sadono Sukirno, 1994;10).

Pertumbuhan ekonomi (economic growth) juga didefinisikan sebagai perkembangan kegiatan dalam perekonomian yang menyebabkan barang dan jasa yang diproduksi dalam masyarakat menjadi bertambah dan kemakmuran masyarakat meningkat dalam jangka panjang. Dengan demikianpembangunan daerah harus sesuai dengan kondisi potensi serta aspirasi masyarakat yang tumbuh dan berkembang. Apabila pelaksanaan prioritas pembangunan daerah kurang sesuai dengan potensi yang dimiliki oleh masing-masing daerah, maka pemanfaatan sumber daya yang ada akan menjadi kurang optimal. Keadaan tersebut dapat mengakibatkan lambatnya proses pertumbuhan ekonomi daerah yang bersangkutan.

Masalah pokok dalam pembangunan daerah berada pada penekanan terhadap kebijakan-kebijakan pembangunan yang berdasarkan pada kekhasan daerah yang bersangkutan dengan menggunakan potensi sumber daya manusia, kelembagaan, dan sumber daya fisik secara lokal (daerah). Sehingga perlu melakukan pengambilan iniseatifiniseatif yang berasal dari daerah tersebut dalam proses pembangunan untuk menciptakan kesempatan kerja baru dan merangsang kegiatan ekonomi.

Pembangunan ekonomi daerah merupakan suatu proses yang mencakup pembentukan-pembentukan institusi baru, pembangunan industri-industri alternatif, perbaikan kapasitas tenagakerja yang ada untuk menghasilkan produk dan jasa yang lebih baik, identifikasi pasar-pasar baru, dan pengembangan perusahaan-perusahaan baru.

Setiap upaya pembangunan ekonomi daerah mempunyai tujuan utama untuk meningkatkan jumlah dan jenis peluang kerja untuk masyarakat daerah. Untuk mencapai tujuan tersebut, pemerintah daerah dan masyarakat harus secara bersama-sama mengambil iniseatif pembangunan daerah. Oleh karena itu pemerintah daerah beserta pertisifasi masyarakatnya dan dengan menggunakn potensi sumber daya yang diperlukan untuk merancang dan membangun perekonomian daerah.

Melalui otonomi daerah, pemerintah dituntut kreatif dalammengembangkan perekonomian, peranan investasi swasta dan perusahaan milikdaerah sangat diharapkan sebagai pemacu utama pertumbuhan dan pembangunanekonomi. Investasi akan mampu mendorong pertumbuhan ekonomi daerah dandapat menimbulkan multiplier effect terhadap sektor-sektor lainnya. Dimana permasalahan terjadi ketika sumber daya alam sebagai faktor produksi tidak bisa dimanfaatkan dengan baik oleh masyarakat lantaran tidak ada barang modal, dalam hal ini adalah mesin.Hal iniselalu menjadi hal yang 


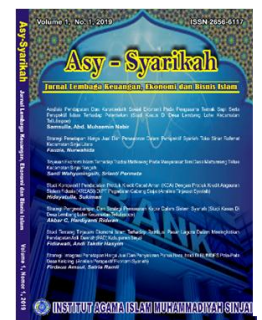

Asy-Syarikah

Jurnal Lembaga Keuangan, Ekonomi dan Bisnis Islam

Volume 2, No. 1, 2020

ISSN (print) : 2656-6117

ISSN (online) : 2715-0356

Homepage : http://journal.iaimsinjai.ac.id/index.php/asy-syarikah

mengerem ata memperlamabat tingkat laju pertumbuhan ekonomi yang di daerah kabupaten Bone.

Pada tahun 2011 sampai pada tahun 2012, tidak mengalami pertumbuhan ekonomi di Kabupaten Bone, sedangkan pada tahun 2013 justru mengalami penurunan pertumbuhan ekonomi Kabupaten Bone yaitu dari tahun 2012 sebesar 8,21 persen sedangakan pada tahun 2013 turun menjadi 6,30 persen, namun pada tahun 2014 mengalami pertumbuhan ekonomi sebesar 9,53 persen, namun pada tahun 2015 mengalami penurunan sebesar 8,30 persen. secara umum laju pertumbuhan ekonomi Kabupaten Bone melambat. Laju pertumbuhan PDRB Kabupaten Bone tahun 2015 sebesar 8,30 persen. Nilai ini lebih kecil dibanding pertumbuhan ekonomi tahun 2014 yang laju pertumbuhannya mencapai 9,53 persen. Selama kurun waktu 2011-2015, laju pertumbuhan PDRB Kabupaten Bone menunjukkan tren yang menurun dari tahun ke tahun, .

Perencanaan pembangunan ekonomi daerah bisa di anggap sebagai perencana untuk memperbaiki pembangunan sumber daya publik yang tersedia di daerah tersebut dan untuk memperbaiki kapasitas sektor swasta dalam menciptakan nilai-nilai sumber daya swasta secara bertanggung jawab. Sektor-sektor ekonomi yang termasuk dalam komponen PDRB dengan menggunakan tahun dasar 2010 terdiri dari 17 kategori yaitu :1) Pertanian, Kehutanan dan Perikanan, 2) Pertambangan dan Penggalian, 3) Indstri Pengolahan, 4) Pengadaan Listrik dan Gas, 5) Pengadaan Air, Pengolahan Sampah, Limbah dan Daur Ulang, 6) Konstruksi, 7) Perdagangan Besar dan Eceran, Reparasi Mobil danSepeda Motor, 8) Trasfortasi dan Pergudangan, 9)Penyediaan Akomodasi dan Makan Minum, 10) Informasi dan Komunikasi, 11) Jasa Keuangan dan Asuransi, 12) Real Estate, 13) Jasa Perusahaan, 14) Administrasi Pemerintahan, Pertahanan, dan Jaminan Sosial Wajib, 15) Jasa Pendidikan, 16) Jasa Kesehatan dan Kegiatan Sosial, 17) Jasa lainnya.

Dengan melihat kondisi di atas, maka timbul pertanyaan apa yang menyebabkan pergeseran struktur perekonomian di Kabupaten Bone. Apakah karena faktor eksternal yang berupa perubahan perekonomian di tingkat provinsi atau apakah karena daya saing daerah yang dimiliki Kabupaten Bone. Kemudian apakah perubahan kontribusi sektoral yang terjadi telah didasarkan kepada strategi kebijakan pembangunan yang tepat, yaitu strategi yang memberikan dampak yang optimal bagi pertumbuhan ekonomi, peningkatan kesempatan kerjadan peningkatan kesejahteraan penduduk. Untuk melaksanakanpembangunan dengan sumber daya yang terbatas sebagai konsekuensinya harusdifokuskan kepada pembangunan sektor-sektor yang memberikan dampak pengganda (multiplier effect) yang besar terhadap sektor-sektor lainnya atau perekonomian secara keseluruhan.

Berdasarkan latar belakang penulis merumuskan rumusan masalah dalam penelitian ini adalah Sektor apa yang menjadi sektor basis dan non basis terhadap suatu sektor ekonomi di kabupatenBone ? Bagaimana perubahan dan pergeseran struktur perekonomian di Kabupaten Bone 2011-2015 ? Bagaimanakah posisi dari klasifikasi pertumbuhan sektor ekonomi Kabupaten Bone?

\section{Metode Penelitian}

\subsection{Jenis Penelitian}

Adapun jenis penelitian yang digunakan dalam penelitian ini adalah jenis penelitian kuantitatif.

\subsection{Sumber Data}

Dalam penelitian ini sumber data yang digunakan adalah data sekunder. 


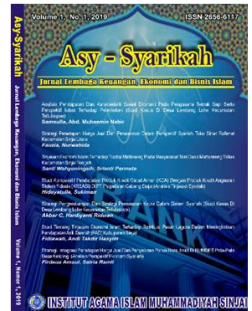

Asy-Syarikah

Jurnal Lembaga Keuangan, Ekonomi dan Bismis Islam

Volume 2, No. 1, 2020

ISSN (print) : 2656-6117

ISSN (online) : 2715-0356

Homepage : http://journal.iaimsinjai.ac.id/index.php/asy-syarikah

\subsection{Lokasi Penelitian}

Penelitian ini dilakukan di wilayah Kabupaten Bone yang tepatnya di kantor Badan Pusat Statistik (BPS) kabupaten Bone provinsi Sulawesi selatan.

\subsection{Populasi dan Sampel}

Populasi dalam penelitian ini adalah semua Data Produk Domestik Regional Broto (PDRB) Kabupaten yang ada di Provinsi Sulawesi Selatan.Teknik pengambilan sampel dalam penelitian ini adalah purposive sampling. Dasar pertimbangan penulis bahwa dalam pengambilan sampel, penulis memilih langsung objek atau wilayah yaitu data Produk Domestik Regional Bruto (PDRB) Provinsi Sulawesi Selatan dan Kabupaten Bone dalam kurung waktu 5 tahun terakhir yaitu tahun $2011 \mathrm{~s} / \mathrm{d} 2016$.

\subsection{Tekhnik Pengumpulan Data}

a. Dokumentasi

Teknik ini digunakan untuk mendapatkan data melalui dokumen atau laporan tertulis lainnya yang berhubungan dengan objek penelitian yang diperoleh dari Bada Pusat Statistik (BPS).

b. Wawancara

Wawancara adalah teknik pengumpulan data dengan melakukan tanya jawab mengenai hal-hal yang berkenaan dengan yang akan diteliti. Teknik ini digunakan untuk melengkapi data yang diperoleh melalui dokumentasi.

\section{c. Tekhik Analisis Data}

\section{1) Analisis Location Quotient (LQ)}

Untuk menentukan sektor basis dan non basis di Kabupaten Bone, digunakan metode analisis Location Qoutient (LQ). Metode ini membandingkantentang besarnya peranan suatu sektor di suatu daerah terhadap besarnya peranansektor tersebut di tingkat nasional atau di tingkat regional. Teknik ini digunakanuntuk mengidentifikasi potensi internal yang dimiliki daerah tersebut yaitu sektorbasis dan merupakan sektor non basis (Kuncoro, 2004).

$$
\begin{aligned}
& \mathrm{V}_{1}^{\mathrm{G}} \mathrm{V}^{\mathrm{G}} \\
& \mathrm{LQ}=\frac{-}{\mathrm{V}_{1}}: \mathrm{V}
\end{aligned}
$$

Dimana :

LQ : Index Location Quotient

$\mathrm{V}_{1}{ }^{\mathrm{G}}$ : Jumlah PDRB suatu sektor $i$ di Kabupaten Bone pada tahun tertentu

$\mathrm{V}^{\mathrm{G}}$ : Jumlah PDRB seluruh sektor di Kabupaten Bone pada tahun tertentu

$\mathrm{V}_{1}$ : Jumlah PDRB suatu sektori di Provinsi Sulawesi Selatan pada tahun tertentu

V: Jumlah PDRB seluruh total sektor Provinsi Sulawesi Selatan pada tahun tertentu

Data yang digunakan dalam analisis LQ ini adalah PDRB Kabupaten Bone dan Provinsi Sulawesi Selatan menurut lapangan usaha atas dasar harga konstan 2000. 
Volume 2, No. 1, 2020

ISSN (print) : 2656-6117

ISSN (online) : 2715-0356

Homepage : http://journal.iaimsinjai.ac.id/index.php/asy-syarikah

2) Analisis Shift Share (S-S)

Analisis Shift Share merupakan teknik yang sangat berguna dalam menganalisis perubahan struktur ekonomi daerah dibandingkan dengan perekonomian nasional.

Secara matematis, Provincial Share (PS), Proportional Shift (P), dan Differential Shift (D) dapat diformulasikan sebagai berikut :

1. Provincial Share (PS)

$$
P S_{i n}^{t}=Y_{i n}^{t-1} \cdot\left(\frac{Y_{N}^{t}}{Y_{N}^{t-1}}-1\right)
$$

2. Proportional Shift $(\mathrm{P})$

$$
P_{i n}^{t}=Y_{i n}^{t-1} \cdot\left(\frac{Y_{i N}^{t}}{Y_{i N}^{t-1}}-\frac{Y_{N}^{t}}{Y_{N}^{t-1}}\right)
$$

3. Differential Shift (D)

4.

$$
\begin{array}{ll}
\text { Dimana : } & \\
\mathrm{Y} & =\text { Total output } \\
\mathrm{t} & =\text { Tahun } 2015 \\
\mathrm{t}-1 & =\text { Tahun } 2011 \\
\mathrm{i} & =\text { Sektor dalam PDRB } \\
\mathrm{r} & =\text { Kabupaten Bone } \\
\mathrm{n} & =\text { Provinsi Sulawesi Selatan }
\end{array}
$$$$
D_{i n}^{t}=Y_{i n}^{t-1} \cdot\left(\frac{Y\left({ }_{i n}^{t}\right)}{Y_{i n}^{t-1}}-\frac{Y_{N}^{t}}{Y_{N}^{t-1}}\right)
$$

Perubahan nilai tambah bruto atau Regional Change (RC) sektor tertentudalam PDRB Kabupaten Bone merupakan penjumlahan dari Provincial (PS),Proportional Shift (P), Differential Shift (D) yaitu :

$$
\mathrm{RC}_{\mathrm{ir}, \mathrm{t}}=\mathrm{P}_{\mathrm{ir}, \mathrm{t}}+\mathrm{PS}_{\mathrm{ir}, \mathrm{t}}+=\mathrm{DSS}_{\mathrm{ir}, \mathrm{t}}
$$

\section{3) Analisis Tipologi Klassen}

Tabel Klasifikasi Tipologi Klassen Pendekatan Sektoral

\section{KUADRAN I SEKTOR PRIMA}

Sektor, subsektor, yang maju dan tumbuh dengan pesat $(\mathrm{Si}>\mathrm{S})$ dan $(\mathrm{Ski}>\mathrm{Sk})$

\section{KUADRAN III SEKTOR BERKEMBANG}

Sektor, subsektor masih dapat berkembang dengan pesat. $(\mathrm{Si}>\mathrm{S})$ dan $(\mathrm{Ski}<\mathrm{Sk})$

\section{KUADRAN II} SEKTOR POTENSIAL

Sektor, subsektor, potensial. $(\mathrm{Si}<\mathrm{S})$ dan $(\mathrm{Ski}>\mathrm{Sk})$

\section{KUADRAN IV SEKTOR KETERBELAKANGAN IV}

Sektor, subsektor yang relatif tertinggal $(\mathrm{Si}<\mathrm{S})$ dan $(\mathrm{Ski}<\mathrm{Sk})$ 
Volume 2, No. 1, 2020

ISSN (print) : 2656-6117

ISSN (online) : 2715-0356

Homepage $\quad:$ http://journal.iaimsinjai.ac.id/index.php/asy-syarikah

Keterangan :

- $\quad S i=$ Rata-rata pertumbuhan Kabupaten Bone

- $S=$ Rata-rata pertumbuhan Sulawesi selatan

- $\quad$ Ski = Rata-rata kontribusi Kabupaten Bone

- $\quad S k=$ Rata-rata kontribusi Sulawesi Selatan

\section{Hasil Penelitian Dan Pembahasan}

\subsection{Pertanian, Kehutanan, dan Perikanan}

Lapangan usaha ini mencakup Sublapangan Usaha Pertanian, Kehutanan, dan Perikanan yanga terdiri dari tanaman pangan, tanaman holtikultura, peternakan, dan jasa pertanian dan perburuan, Sub Lapangan Usaha kehutanan dan Penebangan Kayu, dan Sub Lapangan Usaha Perikanan. Lapangan usaha ini masih menjadi tumpuan dan harapan dalam penyerapan tenaga kerja.

Pada tahun 2015 Lapangan usaha Pertanian, Kehutanan, dan Perikanan memberikan konstribusi terhadap PDRB atas dasar harga berlaku sebesar 49,13 persen. Sub lapangan usaha tanaman pangan merupakan penyumbang terbesar terhadap lapangan usaha pertanian yaitu mencatat sebesar 17,08 persen dari seluruh nilai tambah pertanian. Sedangakan pertumbuhan lapangan usaha ini melambat dari 13,31 persen pada tahun 2014 menjadi 8,95 persen pada tahun 2015 .

Pertumbuhan ekonomi tahun 2015 pada lapangan usaha pertanian, kehutanan dan perikanan terbesar adalah pada lapangan perikanan sebesar 11,76 persen yang diikuti oleh lapangan usaha tanaman pangan sebesar 8,40 persen, menyusul lapangan usaha tanaman holtikultura tahunan dan lainnya sebesar 7,92 persen. Sedangkan lapangan usahalapangan usaha lainya mencetak laju pertumbuhan yang positif di atas 1 persen. Berturutturut lapangan usaha perkebunan tahunan, peternakan, perkebunan musim, tanaman holtikultura semusim, dan jasa pertanmian dan perubahan, hanya lapangan usaha kehutanan dan penebangan kayu yang mengalami resesi ekonomi sampai $-4,80$ persen.

Tabel 4.4. Peranan Lapangan Usaha terhadap PDRB Lapangan Usaha Pertanian, Peternakan, Perburuan dan jasa Pertanian (persen), 2011-2015

$\begin{array}{llllll}\text { Lapangan Usaha / Industry } & 2011 & 2012 & 2013 & 2014 & 2015\end{array}$

\section{(1)}

1. Pertanian, Peternakan, Perburuan dan Jasa Pertanian
a. Tanaman Pangan
b. Tanaman Holtikultura
c. Tanaman Perkebunan
d. Peternakan
e. Jasa Pertanian dan Perkebunan

2. Kehutanan dan Penebangan Kayu

3. Perikanan
(2)

(3)
(5)

(6)

$\begin{array}{llllll}\text { Petanian, Kehutanan, dan Perikanan } & 100,00 & 100,00 & 100,00 & 100,00 & 100,00\end{array}$




\subsection{Pertambangan dan Penggalian}

Lapangan usaha Pertambangan dan Penggalian di Kaupaten Bone hanya di topang oleh sub lapangan penggalian saja. Laju pertumbuhan Lapangan usaha Pertambangan dan Penggalian berfluktuatif dalam priode tahun 2011-2015 yaitu pada tahu 2011 pertumbuhannya 8,47 persen, mengalami percepatan tahun 2012 yaitu 14,57 persen, tetapi tahun 2013 melambat lagi 10,74 persen, pada tahun 2014 menjadi 14,35 persen dan pada tahun 2015 melambat menjadi 13,69 persen.

Sedangkan konstribusinya meningkat dari tahun ke tahun, yaitu 2011 konstribusinya 2,55. Konstribusi tersebut terus meningkat pada tahun 2012, 2013, 2014 masing-masing menjadi 2,68 persen, 2,93 persen, 3,34 persen serta meningkat lagi pada tahun 2015 menjadi 3,74 persen.

Tabel 5.2 Peranan Lapangan Usaha terhadap PDRB Lapangan Usaha Pertambangan dan Penggalian (persen), 2011-2015

\begin{tabular}{cccccc}
\hline Lapangan Usaha / Industry & $\mathbf{2 0 1 1}$ & $\mathbf{2 0 1 2}$ & $\mathbf{2 0 1 3}$ & $\mathbf{2 0 1 4}$ & $\mathbf{2 0 1 5}$ \\
\hline (1) & $\mathbf{( 2 )}$ & $\mathbf{( 3 )}$ & $\mathbf{( 4 )}$ & $\mathbf{( 5 )}$ & $\mathbf{( 6 )}$ \\
\hline 1. Peranan & 2,55 & 2,68 & 2,93 & 3,34 & 3,74 \\
2. Pertumbuhan & 8,47 & 14,57 & 10,74 & 14,35 & 13,69 \\
\hline
\end{tabular}

Sumber : PDRB Kabupaten Bone

\subsection{Industri Pengolahan}

Pada kategori industry Pengolahan, lapangan usaha yang menyumbang peranan terbesar terhadap PDRB adalah Industri makanan dan Minuman yaitu sebesar 5,28 persen pada tahun 2015.

Tabel 5.3 Peranan Sub Lapangan Usaha Industri Pengolahan terhadap PDRB kategori Industri Pengolahan (Persen) 2011-2015

$\begin{array}{lccccc}\text { Lapangan Usaha / Industry } & \mathbf{2 0 1 1} & \mathbf{2 0 1 2} & \mathbf{2 0 1 3} & \mathbf{2 0 1 4} & \mathbf{2 0 1 5} \\ \begin{array}{l}\text { (1) } \\ \text { Industri Batubara dan Penggalian }\end{array} & & \mathbf{( 3 )} & \mathbf{( 4 )} & \mathbf{( 5 )} & \mathbf{( 6 )} \\ \begin{array}{l}\text { Migas } \\ \text { Industri Makan dan Minum }\end{array} & 67,51 & 70,72 & 71,96 & 73,45 & 47,12 \\ \text { Industri Pengolahan Tembakau } & 0,40 & 0,44 & 0,43 & 0,45 & 0,46 \\ \text { Industri Tekstil dan Pakaian Jadi } & 0,19 & 0,19 & 0,18 & 0,17 & 0,17 \\ \begin{array}{l}\text { Industri Kulit, Barang dari Kulit } \\ \text { dan Alas Kaki }\end{array} & 0,76 & 0,74 & 0,74 & 0,69 & 0,64 \\ \begin{array}{l}\text { Industri Anyaman dari Bambu, } \\ \text { Rotan dan Sejenisnya }\end{array} & 8,12 & 6,90 & 6,05 & 5,90 & 5,58\end{array}$


Homepage : http://journal.iaimsinjai.ac.id/index.php/asy-syarikah

Lapangan Usaha / Industry

7. Industri Kertas dan Bahan dari Kertas; Percetakan dan Reproduksi Media Rekaman

8. Industri Kimia, Farmasi dan Obat Tradisioanl

9. Industri Karet, Bahan dari Karet dan Plastik

10.Industri Barang Galian Bukan Logam

11.Industri Logam dasar

12.Industri Barang Logam; Komputer, Barang elektronik, Optik; dan Peralatan Listrik

13.Industri Mesin dan Perlengkapan

14.Industri Alat Angkutan

15.Industri Furnitur

16.Industri Pengolahan Lainnya; Jasa Reperasi dan Pemasangan Mesin dan Peralatan

Industri Pengolahan

\section{1}

2012

2013

2014

2015

$1,51 \quad 1,47 \quad 1,44 \quad 1,49 \quad 1,50$

0,63

0,60

0,57

0,54

0,55

0,06

0,05

0,05

0,05

0,05

10,58

10,12

10,36

9,78

9,64

$\begin{array}{ccccc}9,01 & 7,64 & 7,21 & 6,47 & 6,27 \\ - & - & - & - & - \\ 0,57 & 0,58 & 0,52 & 0,48 & 0,48 \\ 0,54 & 0,43 & 0,37 & 0,43 & 0,45 \\ 0,12 & 0,13 & 0,11 & 0,11 & 0,10 \\ 100,00 & 100,00 & 100,00 & 100,00 & 100,00\end{array}$

Sumber : PDRB Kabupaten Bone

Sedangakan Peranan Sub Lapangan Usaha Industri Pengolahan terhadap PDRB kategori Industri Pengolahn, lapangan usaha yang menyumbang peranan terbesar terhadap PDRB adalah Industri Makan dan Minum yaitu sebesar 74,12 persen pada tahun 2015. Kemudian diikuti oleh Industri Barang galian Bukan Logam9,64 persen.

Secara keseluruhan, laju pertubuhan lapangan usaha industri Pengolahan pada tahu 2015 sebesar 7,33 persen, sedangkan lapangan usaha yang mencatat laju pertumbuhan terbesar adalah Industri Furniture yaitu sebeasr 12,70 persen pada tahun 2015, kemudian diikuti olehindustri Pengolahan tembakau sebesar 10,23 persen, kemudian industri kimia, farmasi dan obat tradisional sebesar 9,17 persen, industri alat angkutan sebesar 6,79 persen dan industri barang galian bukann logam 5,79, sedangkan industri selain yang disebutkan pertumbuhan dibawah 5 persen.

\subsection{Pengadaan Listrik dan Gas}

Lapangan Usaha Pengadaan Listrik dan Gas berkonstribusi sebesar 0,07 persen terhadap perekonomian Kabupaten Bonepada tahun 2015. Dari konstribusi tersebut, sebanyak 93,60 persennya disumbangkan oleh lapangan usaha Ketenagalistrikan, dan 6,40 persen oleh Pengadaan Gas dan Pruduksi Es.

Sedangkan laju pertumbuhan ekonomi lapangan usaha ini mengalami resesi ekonomi sebesar -6,17 persen pada tahun 2015. Masing-masing lapangan usaha juga mencatatkan pertumbuhan, dimana lapangan usaha Ketenagalistrikan sebesar -7,04 persen dan pengadaan gas dan Produksi Es sebesar 8,70 persen. 


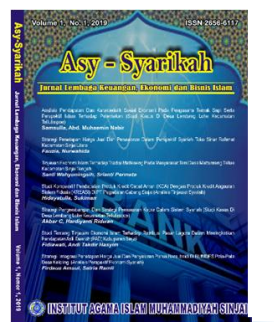

Asy-Syarikah

Jurnal Lembaga Keuangan, Ekonomi dan Bisnis Islam

Volume 2, No. 1, 2020

ISSN (print) : 2656-6117

ISSN (online) : 2715-0356

Homepage : http://journal.iaimsinjai.ac.id/index.php/asy-syarikah

Tabel 5.4 Peranan Lapangan Usaha terhadap PDRB Lapangan Usaha Pengadaan Listrik dan Gas (persen), 2011-2015

\begin{tabular}{cccccc}
\hline Lapangan Usaha / Industry & $\mathbf{2 0 1 1}$ & $\mathbf{2 0 1 2}$ & $\mathbf{2 0 1 3}$ & $\mathbf{2 0 1 4}$ & $\mathbf{2 0 1 5}$ \\
\hline $\mathbf{( 1 )}$ & $\mathbf{( 2 )}$ & $\mathbf{( 3 )}$ & $\mathbf{( 4 )}$ & $\mathbf{( 5 )}$ & $\mathbf{( 6 )}$ \\
\hline 1. Ketenaga listrikan & 2,55 & 2,68 & 2,93 & 3,34 & 3,74 \\
2. Pengadaan Gas dan Produksi Es & 8,47 & 14,57 & 10,74 & 14,35 & 13,69 \\
\hline Pengadaan Listrik dan Gas & 100,00 & 100,00 & 100,00 & 100,00 & 100,00 \\
\hline
\end{tabular}

Sumber : PDRB Kabupaten Bone

\subsection{Pengadaan Air, Pengolahan Sampah, Limbah, dan Daur Ulang}

Lapangan usaha ini mencakup kegiatan ekonomi pengumpulan, pengolahan dan pendistribusian air melalui berbagai saluran pipa untuk kebutuhan rumah tangga dan industri.Termasuk juga kegiatan pengumpulan, penjernian dan pengolahan air dan sungai, danau, mata air, hujan dll. Tidak termasuk pengoperasian peralatan irigasi untuk keperluan pertanian. Peranan lapangan usaha ini terhadap perekonomian di Kabuopaten Bone selama tahun 2011-2013 sebesar 0,05 persen, pada tahun 2014 ada pergeseran sehingga hanya 0,04 persen, begitu pula untuk tahun 2015 hanya 0,03 persen. Sedangkan laju pertumbuhannya yaitu sebesar 10.44 persen, 3,40 persen, 4,79 persen, 0,08 persen dan 0,47 persenberturut-turut untuk tahun 2011-2015.

\subsection{Konstruksi}

Pada tahun 2015 lapangan usaha konstruksi munyumbang sebesar 9,66 persen terhadap total perekonomian Kabupaten Bone meningkat disbanding pada tahun 2014 sebesar 9,55 persen. Trend kontribusi lapangan usaha konstruksi juga terlihat pada priode tahun 2011-2015 yaitu tahun 2011 saebesar 9,79 persen, tahun 2012 sebesar 9,88 persen, tahun 2013 sebesar 10,22 persen, pada tahun 2014 sebesar 9,55 persen dan pada tahu 2015 sebesar 9,66 persen. Dengan perhitungan atas dasar harga konstan 2010, laju pertumbuhan konstruksi Kabupaten Bone tahun 2015 sebesar 7,98 persen.

\subsection{Perdagangan Besar dan Eceran, Reparasi Mobil dan Sepeda Motor}

Selama 5 tahun terakhir, lapangan usaha Perdagangan Besar dan Eceran; Reparasi Mobil dan Sepeda Motor menyumbang di atas 10 persen. Pada tahun 2015, konstribusi lapangan usaha ini sebesar 11,04 persen, dengan sebesar 3,37 persen $(28,64$ persen terhadap lapangan usaha) disumbangkan oleh Perdagangan Mobil, Sepeda Motor dan Reparasinya. Sedangkan sebesar 97,67 persen (71,52 persen terhadap lapangan usaha) disumbangkan oleh lapangan usaha Perdagangan Besar dan Eceran bukan Mobil dan Sepeda Motor. 


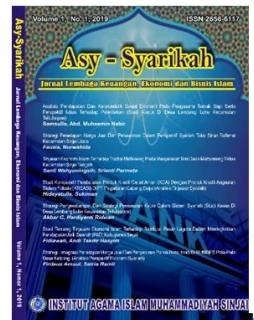

Asy-Syarikah

Jurnall Lembaga Keuangan, Ekonomi dan Bisnis Islam

Volume 2, No. 1, 2020

ISSN (print) : 2656-6117

ISSN (online) : 2715-0356

Homepage : http://journal.iaimsinjai.ac.id/index.php/asy-syarikah

Tabel 5.7 Peranan Lapangan Usaha terhadap PDRB lapangan Usaha Perdagangan Besar dan Eceran; reparasi Mobil dan Sepeda Motor (Persen), 20112015

\begin{tabular}{cccccc}
\hline Lapangan Usaha / Industry & $\mathbf{2 0 1 1}$ & $\mathbf{2 0 1 2}$ & $\mathbf{2 0 1 3}$ & $\mathbf{2 0 1 4}$ & $\mathbf{2 0 1 5}$ \\
\hline $\mathbf{( 1 )}$ & $\mathbf{( 2 )}$ & $\mathbf{( 3 )}$ & $\mathbf{( 4 )}$ & $\mathbf{( 5 )}$ & $\mathbf{( 6 )}$ \\
\hline $\begin{array}{l}\text { 1. Perdagangan Mobil, Sepeda Motor } \\
\quad \text { dan Reparasinya }\end{array}$ & 29,18 & 29,15 & 30,06 & 29,73 & 28,46 \\
$\begin{array}{l}\text { 2. Perdagangan Besar dan Eceran, } \\
\text { Bukan Mobil dan Sepeda Motor }\end{array}$ & 70,82 & 70,85 & 39,94 & 70,21 & 71,52 \\
\hline Pengadaan Listrik dan Gas & 100,00 & 100,00 & 100,00 & 100,00 & 100,00 \\
\hline
\end{tabular}

Sumber : PDRB Kabupaten Bone

\subsection{Trasportasi dan Pergudangan}

Lapangan usaha Transportasi dan Pergudangan terdiri dari 6 sub lapangan usaha, yaitu Angkutan Rel, Angkutan Darat, Angkutan Laut, Angkutan Sungai, Danau dan Penyeberangan, Angkatan Udara, Serta Pergudangan dan Jasa Penunjang Angkutan.

Tabel 5.8

Peranan Lapangan Usaha terhadap PDRB Lapangan usaha Transportasi dan Pergudangan (Persen), 2011-2015.

\begin{tabular}{|c|c|c|c|c|c|}
\hline Lapangan Usaha / Industry & 2011 & 2012 & 2013 & 2014 & 2015 \\
\hline (1) & (2) & (3) & (4) & (5) & (6) \\
\hline 1. Angkutan Rel & 0,00 & 0,00 & 0,00 & 0,00 & 0,00 \\
\hline 2. Angkutan Darat & 73,62 & 74,78 & 75,63 & 74,36 & 75,31 \\
\hline 3. Angkutan Laut & 4,72 & 4,78 & 4,94 & 5,74 & 5,11 \\
\hline $\begin{array}{l}\text { 4. Angkutan Sungai Danau dan } \\
\text { Penyeberangan }\end{array}$ & 20,68 & 19,45 & 18,34 & 19,17 & 18,59 \\
\hline 5. AngkutanUdara & 0,00 & 0,00 & 0,00 & 0,00 & 0,00 \\
\hline $\begin{array}{l}\text { 6. Pergudangan dan Jasa Penunjang } \\
\text { Angkuta; Pos dan Kurir }\end{array}$ & 0,98 & 0,98 & 0,98 & 0,90 & 0,89 \\
\hline Transportasi dan Pergudangan & 100,00 & 100,00 & 100,00 & 100,00 & 100,00 \\
\hline
\end{tabular}

Lapangan usaha Anguktan darat memberikan Konstribusi terbesar selama 5 tahun terakhir, dengan nilai konstribusi terhadap lapangan usaha ini sebesar 75,31 persen pada tahun 2015. Sedangkan penyumbang terbesar berikutnya adalah Angkutan Sungai, danau, dan Penyeberangan 18,59 persen dan angkutan laut 5,11 persen. 


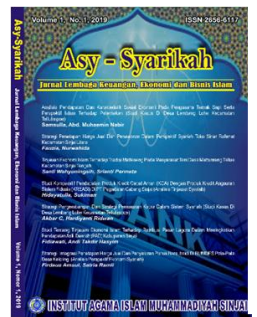

Asy-Syarikah

Jurnal Lembaga Keuangan, Ekonomi dan Bisnis Islam

Volume 2, No. 1, 2020

ISSN (print) : 2656-6117

ISSN (online) : 2715-0356

Homepage : http://journal.iaimsinjai.ac.id/index.php/asy-syarikah

\subsection{Penyediaan Akomodasi dan Makan Minum}

Pada tahun 2015, Lapangan Usaha Penyediaaan Akomodasi danMakan Minum memberikan konstribusi terhadap PDRB Kabupaten Bone sebesar 0,51 persen, dimana sebesar 0,45 persennya merupakan konstribusi dari lapangan usaha Penyediaan Makan dan Minum sebesar 0,06 persen (10,71 persen terhadap lapangan usaha) disumbangkan oleh lapangan usaha Penyediaan Akomodasi. Secara keseluruhan, lapangan usaha ini mencetak laju pertumbuhan positif sebesar 4,07 persen pada tahun 2015 .

Tabel 5.9 Peranan Lapangan Usaha terhadap PDRB Lapangan usaha Penyediaan Akomodasi dan Makan Minum (perse) 2011-2015.

\begin{tabular}{lccccc}
\hline \multicolumn{1}{c}{ Lapangan Usaha / Industry } & $\mathbf{2 0 1 1}$ & $\mathbf{2 0 1 2}$ & $\mathbf{2 0 1 3}$ & $\mathbf{2 0 1 4}$ & $\mathbf{2 0 1 5}$ \\
\hline \multicolumn{1}{c}{$(\mathbf{1})$} & $\mathbf{( 2 )}$ & $\mathbf{( 3 )}$ & $\mathbf{( 4 )}$ & $\mathbf{( 5 )}$ & $\mathbf{( 6 )}$ \\
\hline 1. Penyediaan akomodasi & 11,21 & 11,54 & 11,62 & 10,98 & 10,71 \\
2. Penyediaan Makan Minum & 88,79 & 88,46 & 88,38 & 89,02 & 89,29 \\
\hline Transportasi dan Pergudangan & $\mathbf{1 0 0 , 0 0}$ & $\mathbf{1 0 0 , 0 0}$ & $\mathbf{1 0 0 , 0 0}$ & $\mathbf{1 0 0 , 0 0}$ & $\mathbf{1 0 0 , 0 0}$ \\
\hline Sumber : PDRB Kabupaten Bone & & & & &
\end{tabular}

\section{Informasi dan Komunikasi}

Lapangan usaha informasi dan komunikasi memiliki peranan sebagai penunjang aktivitas setiap bidang ekonomi.Dalam era globalisasi, peranan lapangan usaha ini sangat vital dan menjadi indicator kemajuan suatu bangsa, terutama jasa telekomunikasi. Peranan lapangan usaha ini terdapat perekonomian di kabupaten Bone selama tahun 2011-2015 sebesar 1,82 persen, 1,86 persen, 1,86 persen, 1,50 persen, dan 1,35 persen. Sedangkan laju pertumbuhannya pada tahun 2015 sebesar 10,44 persen.

\section{a. Jasa Keuangan dan Asuransi}

Kegiatan Ekonomi pada lapangan usaha jasa perantaa keuangan menjadi penyumbang mayoritas konstribusi perekonomian pada lapangan usaha jasa keuangan dan asuransi ini.Selama tahun 2011-2015, konstribusinya mendominasi dengan lebih dari 59 persen terhadap PDRB lapangan usaha jasa keuangan dan asuransi. Penyumbang terbesar berikutnyta dalam lapangan usaha jasa keuangan lainya pada kisaran di atas 32 persen, Asuransi dan Dana Pensiun dengan sumbangan sekitar 6 persen, dan terakhir dalam jasa Penunjang keuangan dengan nilai konstribusi terhadap lapangan usaha ini sekitar 1 persen.

b. Real Estate

Lapangan usaha real state memberikan konstribusi yang sangat relative stabil bagi PDRB Kabupaten Bone dengan peranan sebesar kurang dari 4 persen. Selama tahun 2011-2015, secara berturut-turut sumbangan lapangan usaha real state sebesar 3,58 persen, 3,79 persen, 3,90 persen, 3,78 persen dan 3,82 persen. Sedangkan laju pertumbuhan ekonomi lapangan usaha ini berfluktuasi sepanjang tahun 2011-2015 yaitu berkisar 9,90 persen, 5,52 persen, 7,54 persen dan 7,38 persen. 


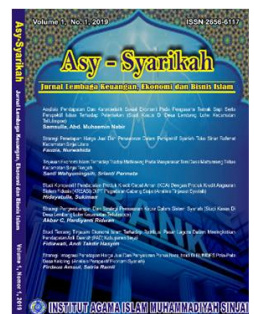

Asy-Syarikah

Jurnal Lembaga Keuangan, Ekonomi dan Bisnis Islam

Volume 2, No. 1, 2020

ISSN (print) : 2656-6117

ISSN (online) : 2715-0356

Homepage : http://journal.iaimsinjai.ac.id/index.php/asy-syarikah

\section{c. Jasa Perusahaan}

Selama 5 tahun terakhir, kontribusi kegiatan ekonomi pada lapangan usaha jasa perusahaan yaitu 0,07 dari tahun 2011-2013, akan tetapi pada tahun 2014-2015 mengalami pergeseran yaitu 0,06 persen. Hal ini menunjukkan pula peran lapangan usaha ini relative kecil dibandingkan peranan lapangan usaha-lapangan usaha lainnya pada perekonomian Kabupaten Bone, sedangakan laju pertumbuhannya pada tahun 2015 sebesar 6,57 persen.

\section{1) Administrasi Pemerintah, pertahanan, dan Jaminan Sosial Wajib}

Lapangan usahga ini meliputi kegiatan yang sifatnya pemerintaha, yang umumnya dilakukan oleh administrasi pemerintahan termasuk juga perundangundangan dan penterjemahan hukum yang berkaitan dengan pengadilan dan menurut peraturannya. Selama tahun 2011-2015 peranannya pada kisaran 4-5 persen, yaitu dengan nilai kontribusi sebesar 5,64 persen, 5,19 persen, 4,89 persen, 4,58 persen dan 4,77 persen. Sedangkan laju pertumbuhannya pada tahun 2015 mencapai 9,34 persen.

\section{2) Jasa Pendidik}

Pada tahun 2015 jasa pendidikan menyumbang sebesar 2,25 persen terhadap total perekonomian kabupaten Bone, menurun dibandingkan dengan tahun 2014sebesar 2,35 persen. Kontribusi lapangan usaha ini juga terlihat sedikit berfluktuasi pada tahun 2011-2013 yaitu sebesar berturut-turut 2,53 persen, 2,43 persen dan 2,48 persen. Dengan perhitungan atas dasar harga konstan 2010, laju pertumbuhan jasa pendidikan Kabupaten Bone sebesar 6,52 persen pada tahun 2015 .

\section{3) Jasa Kesehatan dan Kegiatan Sosial}

Lapangan usaha ini mencakup kegiatan penyadiaan jasa kesehatan dan kegiatan sosial yang cukup luas cakupannya. Pada tahun 2015, konstribusinya terhadap perekonomian kabupaten Bone sebesar 0,86 persen dengan laju pertumbuhan sebesar 7,66 persen. Selama tahun 2011-2012 peranannya relatif stabil dengan menunjukkkan sedikit peningkatan, yaitu dengan nilai konstribusi sebesar 0,79 persen, 0,84 persen dan tahun 2013-2015 konstribusinya 0,86 persen. Sedangkan laju pertumbuhannya pada tahun 2015 sebesar 7,66 persen.

\section{4) Jasa Lainnya}

Konstribusi jasa lainnya terhadap perekonomian Kabupaten Bone relatif kecil yaitu berturut-turut 0,34 persen pada tahun 2011,0,33 persen pada tahun 2012-2013 dan 0,32 persen pada tahun 2014-2015. Sedangkan laju pertumbuhannya sebesar 7,98 persen pada tahun 2015

\section{Daftar Pustaka}

Adisasmita, R, 2005. Dasar-Dasar Ekonomi Wilayah. Graha Ilmu, Yogyakarta.

Ambardi, U.M dan Socia, P. 2002. Pengembangan Wilayah dan Otonomi Daerah. PusatPengkajian Kebijakan Pengembangan Wilayah, Jakarta.

Arsyad, Lincolin, 1999. Pengantar Perencanaan dan Pembangunan Ekonomi Daerah. BPFE, Yogyakarta. 


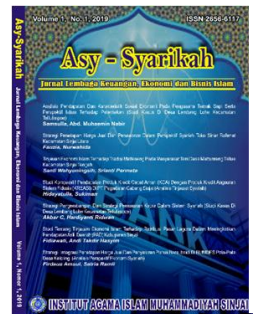

Asy-Syarikah

Jurnal Lembaga Keuangan, Ekonomi dan Bismis Islam

Volume 2, No. 1, 2020

ISSN (print) : 2656-6117

ISSN (online) : 2715-0356

Homepage : http://journal.iaimsinjai.ac.id/index.php/asy-syarikah

Badan Perencanaan Pembangunan Nasional, 2008. Undang-Undang No. 32 Tahun 2004 tentangPemerintahan Daerah, http://www.Bappenas.go.id/node/123/3/uu-no32tahun-2004-tentang-pemerintahan-daerah/, diakses pada tanggal 27 Maret 2012.

Badan Perencanaan Pembangunan Nasional, 2008.Undang-Undang No. 33 Tahun 2004 tentangPemerintahan Daerah http:/www.Bappenas.go.id/node/123 /3/uu-no33tahun-2004-tentang-pemerintahan-daerah/, diakses pada tanggal 27 Maret 2012.

Badan Perencanaan Pembangunan Daerah Kabupaten Bone, 2008. Rencana Pembangunan Jangka Menengah Daerah (RPJMD) 2008-2013 Kabupaten Bone http://www.bone.go.id/download/PERDA\%20RPJMD. pdf, diakses tanggal 4 April 2012.

Badan Pusat Statistik Kabupaten Bone, 2011. Produk Domestik Regional Bruto Kabupaten Bone2011. Pemerintah Kabupaten Bone, Watampone.

Badan Pusat Statistik Kabupaten Bone, 2011. Kabupaten Bone dalam Angka. Pemerintah Kabupaten Bone, Watampone.

Badan Pusat Statistik Provinsi Sulawesi Selatan, 2011. Produk Domestik Regional Bruto Kabupaten Bone 2011. Pemerintah Provinsi Sulawesi Selatan, Makassar.

Basuki, Agus Tri, 2005. "Peranan Kabupaten Way Kanan dalam Pembentukan PDRB ProvinsiLampung Tahun 1999-2002", Skripsi. Universitas Sriwijaya, Palembang.

Boediono, 1999. Teori Pertumbuhan Ekonomi. BPFE, Yogyakarta.

Fachrurrazy, 2009. “Analisis Penentuan Sektor Unggulan Perekonomian Wilayah Kabupaten Aceh Utara dengan Pendekatan Sektor Pembentuk PDRB”. Tesis, Sekolah Pasca Sarjana Universitas Sumatera Utara, Medan.

Ghufron, Muhammad. 2008. “Analisis Pembangunan Wilayah Berbasis Sektor Unggulan Kabupaten Lamongan Provinsi Jawa Timur”.Skripsi, Institut Pertanian Bogor, Bogor.

Gravitiani, Evi, 2006. "Analisis Shift-Share Dinamik pada Perekonomian Yogyakarta". Skripsi,FE-UGM, Yogyakarta.

Jhingan, ML, 2002. Ekonomi Pembangunan. Penerbit Rajawali, Jakarta.

Kuncoro, M, 2004. Otonomi dan Pembangunan Daerah; Reformasi, Perencanaan, Strategi danPeluang. Erlangga, Jakarta.

Purwaningsih, 2009. "Analisis Struktur Ekonomi dan Penentuan Sektor Unggulan Kabupaten Parigi Moutong”, Skripsi. Institut Pertanian Bogor, Bogor.

Sjafrizal, 2008. Ekonomi Regional : Teori dan Aplikasi. Badouse Media, Cetakan Pertama, Padang.

Soepono, Prasetyo, 1993. Analisis Shift-Share Perkembangan dan Penerapan, JEBI, No.1, Tahun III.

Sukirno, Sadono, 1985. Ekonomi Pembangunan: Proses, Masalah dan Dasar Kebijakan. LPFEUI, Jakarta. 


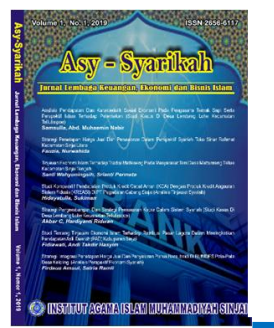

Asy-Syarikah

Jurnal Lembaga Keuangan, Ekonomi dan Bisnis Islam

Volume 2, No. 1, 2020

ISSN (print) : 2656-6117

ISSN (online) : 2715-0356

Homepage : http://journal.iaimsinjai.ac.id/index.php/asy-syarikah

Suryana, 2000. Teori-teori Pertumbuhan Ekonomi, Ekonomi Pembangunan: Teori, Masalah danKebijakan. UPP AMP YKPN Yogyakarta.

Tambunan, Tulus. 2001. Perekonomian Indonesia. Ghalia Indonesia, Jakarta.

Tarigan, Robinson, 2007. Ekonomi Regional, Teori dan Aplikasi, PT Bumi Aksara, CetakanKeempat, Jakarta.

Tarmidi, Lepi T, 1992. Ekonomi Pembangunan. Pusat Antar Universitas EK-UI, Jakarta.

Todaro, Michael P, 2000. Ekonomi Untuk Negara Berkembang Suatu Pengantar Tentang Prinsip-prinsip Masalah dan Kebijakan Pembangunan. Bumi Aksara, 